\title{
KAPSUL VITAMIN A DAN MORBIDITAS ANAK BALITA: ANALISIS DATA RISKESDAS 2007
}

\author{
Endi Ridwan \\ Peneliti Pusat Teknologi Terapan Kesehatan dan Epidemiologi Klinik
}

\begin{abstract}
ABSTRAK
Suplementasi kapsul vitamin A dosis tinggi pada anak balita dapat mempengaruhi mortalitas dan morbiditas penyakit infeksi saluran pernafasan dan diare. Suplementasi kapsul vitamin A menyebabkan mortalitas terhadap penyakit diare dan saluran pernafasan berkurang sebanyak 34 persen. Namun dampak suplementasi terhadap morbiditas penyakit infeksi bervariasi menurut jenis penyakit, berat ringan penyakit, umur sampel. Tulisan ini bertujuan untuk menilai dampak suplementasi vitamin A pada balita terhadap morbiditas penyakit diare, infeksi saluran pernafasan akut (ISPA), pneumonia, campak, dan demam tifoid dengan menggunakan data sekunder 70.650 sampel anak balita 12-59 bulan pada Riskesdas 2007. Pengumpulan data morbiditas dilakukan berdasarkan wawancara lima penyakit tersebut satu bulan terakhir sebelum pengumpulan data yang didiagnosa tenaga kesehatan atau tanda dan gejala penyakit. Hasil analisis data Riskesdas 2007 menunjukkan bahwa total cakupan kapsul vitamin A 72 persen, lebih tinggi cakupan di perkotaan. Proporsi anak dengan diagnosa ISPA, pneumonia, demam tifoid, diare, campak masing-masing 16,4 persen, 1,0 persen, 0,8 persen, 11,6 persen, dan 2,4 persen, sedangkan proporsi dengan gejala penyakit tersebut masing-masing 31,5 persen, 1,9 persen, 0,8 persen, 6,1 persen, dan 1,0 persen. Analisis tidak menemukan perbedaan proporsi penyakit pneumonia, demam tifoid dan campak pada anak yang menerima atau tidak kapsul vitamin A. Proporsi ISPA dan diare pada balita yang menerima kapsul vitamin A lebih tinggi dibanding anak yang tidak menerima kapsul vitamin A. Hal ini diduga karena beberapa sebab yang mempengaruhi waktu survei, distribusi kapsul, faktor perancu, dan kejadian ISPA dan diare.
\end{abstract}

Kata kunci: kapsul vitamin A, balita, morbiditas, diare, ISPA, pneumonia, campak

ABSTRACT

\section{VITAMIN A CAPSULE AND CHILD MORBIDITY DATA ANALYSIS RISKESDAS 2007}

Studies showed that high-dose vitamin A capsules reduce child mortality due to acute respiratory infection and diarrhea by 34 percent. However, there have been inconsistency on the impact of vitamin A capsules on morbidity, depending on different infectious diseases, severity, and age of samples. The objective of the paper is to measure the impact of vitamin A capsules on five infectious diseases by using secondary data of Riskesdas (Baseline Health Research) 2007 of 70.650 Indonesian children 12-59 month old. Pre-tested questionnaires were used to collect vitamin A capsules received within six months prior to data collection, five infectious diseases within one month prior to data collection. The results showed that the overall coverage of vitamin A capsules was 72 percent, higher coverage in urban areas. The proportion of children diagnosed for acute respiratory infection, pneumonia, typhoid fever, diarrhea, measles were $16,4 \%, 1,0 \%, 0,8 \%, 11,6 \%$, and $2,4 \%$ respectively, while the proportion of children having signs and symptoms of the diseases were $31,5 \%, 1,9 \%, 0,8 \%, 6,1 \%$, and $1,0 \%$. The analyses showed that there was no difference of children who received vitamin $A$ or not on the proportion of pneumonia, typhoid fever, and measles. There was a higher proportion of acute respiratory infection and diarrhea among children who received vitamin A capsules compared to those did not receive. It is assumed that there may be confounding factors affecting the finding of the analysis.

Keywords: vitamin A capsules, underfives, morbidity, diarrhea, acute respiratory infection, pneumonia, measles

\section{PENDAHULUAN}

$\mathrm{M}$ asalah kurang vitamin A merupakan salah satu masalah gizi utama di Indonesia dengan prevalensi yang tinggi pada wanita dan anak balita. Dengan prevalensi yang tinggi tersebut merupakan penyebab utama dari meningkatnya morbiditas, mortalitas dan kebutaan. ${ }^{1}$ Suplementasi vitamin A dosis tinggi yang diberikan dua kali setahun terbukti berdampak meningkatkan status vitamin A, aman, dan merupakan intervensi 
yang cost-effective. International Vitamin $A$ Consultative Group (IVACG) merekomendasikan bahwa kapsul vitamin A dapat juga diberikan kepada anak yang menderita campak, diare, gizi buruk, anak kurang vitamin A dengan tanda bercak Bitot, dan buta senja. Pelaksanaan program suplementasi harus secara efektif dapat menjangkau balita dengan cakupan yang tinggi. ${ }^{2}$

Indonesia sudah melaksanakan rekomendasi tersebut dan meluaskan program distribusi kapsul vitamin A sejak tahun 1980-an melalui distribusi kapsul vitamin $A$ dosis tinggi pada anak balita dua kali setahun pada bulan Februari dan Agustus. ${ }^{3}$ Program pemberian kapsul vitamin A untuk anak berumur 12-59 bulan diberikan dengan dosis $60 \mathrm{mg}$ retinol secara oral, dan takaran setengahnya untuk bayi berumur 6-11 bulan, dengan posyandu sebagai tempat utama pemberian kapsul vitamin A pada anak. ${ }^{4}$

Vitamin A memegang peran penting untuk mengurangi mortalitas dan morbiditas penyakit infeksi saluran pernafasan akut dan diare pada anak balita. ${ }^{5}$ Hasil analisis dengan menggunakan data studi Aceh pada anak prasekolah dengan status vitamin A marginal mengungkapkan bahwa mortalitas akibat penyakit infeksi saluran pernafasan akut dan diare menurun dengan 34 persen setelah diberi suplementasi vitamin A, namun dampaknya terhadap morbiditas belum dilaporkan. 1,6

Tulisan ini bertujuan menilai dampak suplementasi vitamin A terhadap morbiditas penyakit ISPA, pneumonia, demam tifoid, diare dan campak menggunakan data sekunder dari data Riskesdas 2007.

\section{METODE PENELITIAN}

Desain Riskesdas 2007 adalah potong lintang dan merupakan penelitian non-intervensi di 440 kabupaten/ kota di 33 provinsi. Populasi sampel mewakili seluruh rumah tangga di Indonesia. Pemilihan sampel dilakukan secara random dalam dua tahap. Tahap pertama melakukan pemilihan Blok Sensus (BS) dan tahap kedua pemilihan 25 rumah tangga setiap BS. Besar sampel yang dikumpulkan sebanyak 17.165 BS, dengan 258.366 sampel rumah tangga di 33 provinsi. ${ }^{7}$
Data yang dikumpulkan dalam Riskesdas 2007 meliputi keterangan rumah tangga, karakteristik individu anggota rumah tangga, pengukuran berat dan tinggi badan termasuk anak balita. Pada tulisan ini tidak semua data rumahtangga, individu, dan pengukuran yang diambil untuk dianalisis, tetapi hanya data yang relevan tentang cakupan vitamin $\mathrm{A}$ dan morbiditas.

Penelitian ini merupakan analisis lanjut dari data Riskesdas 2007. File yang dianalisis adalah file individu. Tidak semua data individu yang dipilih. Tidak semua anak balita diolah dalam analisis ini. Kriteria data yang diolah dalam analisis tulisan ini adalah anak balita berumur 12-59 bulan dengan data yang lengkap dalam karakteristik anak (jenis kelamin, umur, berat dan tinggi badan), penerimaan kapsul vitamin A dalam enam bulan terakhir (ya atau tidak), morbiditas anak dalam satu bulan terakhir sebelum survei (diare, ISPA, pneumonia, campak, demam tifoid) baik hasil diagnosis tenaga kesehatan maupun wawancara berdasarkan gejala penyakit, kuintil pengeluaran rumahtangga, dan tempat tinggal anak.

Status gizi anak dihitung dengan menggunakan baku WHO 2005 menurut indeks underweight $(\mathrm{BB} / \mathrm{U})$, wasting $(\mathrm{BB} / \mathrm{TB})$, stunting (TB/U). Status gizi BB/U dikelompokkan menjadi $\mathrm{BB}$ lebih, baik, $\mathrm{BB}$ kurang, dan $\mathrm{BB}$ sangat kurang, $B B / T B$ dikelompokkan menjadi overweight, normal, kurus dan sangat kurus, TB/U dikelompokkan menjadi normal, pendek, sangat pendek, masing-masing sesuai dengan nilai cut-off yang baku yaitu: $z$-score $<-3.0 \mathrm{SD}$, $-3.0--2.0$ SD, $<-2.0$ SD - +2.0 SD, dan $>+2.0$ SD.

Sebelum dilakukan analisis, dilakukan pembobotan (weight) sesuai dengan weight individu yang tersedia dalam data. Analisis univariat untuk mengetahui proporsi menurut karakteristrik anak, rumahtangga, cakupan kapsul vitamin A, morbiditas, dan status gizi. Untuk analisis bivariat dilakukan dengan tabulasi silang terutama untuk mengetahui perbedaan antara morbiditas penyakit dalam satu bulan terakhir dengan menerima atau tidak kapsul vitamin A dengan menggunakan uji Khikuadrat. 
HASIL

Tabel 1 menunjukkan jumlah sampel yang dianalisis menurut karakteristik tempat tinggal yaitu sebanyak 70.650 balita $12-59$ bulan. Terlihat bahwa sampel balita lebih banyak di perdesaan yaitu 63,5 persen dibanding di perkotaan 36,5 persen.

Persentase sampel pada setiap kelompok umur 12-23, 24-35, 36-47, dan 48-59 bulan hampir sama yaitu lebih banyak sampel tinggal di daerah perdesaan.

Tabel 1

Persen sampel balita 12-59 bulan menurut umur dan tempat tinggal, Riskesdas 2007

\begin{tabular}{lccccc}
\hline \multirow{1}{*}{ Daerah } & \multicolumn{4}{c}{ Umur balita (bulan) } & Total \\
\cline { 2 - 5 } & $\begin{array}{c}12-23 \\
\mathrm{n}=16.950\end{array}$ & $\begin{array}{c}24-35 \\
\mathrm{n}=17.966\end{array}$ & $\begin{array}{c}36-47 \\
\mathrm{n}=18.990\end{array}$ & $\begin{array}{c}48-59 \\
\mathrm{n}=16.744\end{array}$ & $\mathrm{n}=70.650$ \\
\hline Perkotaan & 37,7 & 36,0 & 36,4 & 36,0 & 36,5 \\
Perdesaan & 62,3 & 64,0 & 63,6 & 64,0 & 63,5 \\
\hline
\end{tabular}

Tabel 2 mengungkapkan jumlah sampel menurut karakteristik jenis kelamin. Persentase sampel anak laki-laki lebih banyak yaitu sebanyak 51,1 persen dibanding dengan anak perempuan sebanyak 48,9 persen. Persentase tersebut terdistribusi merata pada golongan umur 12-23, 24-35, 36-47 dan 48- 59 bulan.

Tabel 2

Persen sampel balita 12-59 bulan menurut umur dan jenis kelamin, Riskesdas 2007

\begin{tabular}{lccccc}
\hline \multirow{2}{*}{ Jenis kelamin } & \multicolumn{4}{c}{ Umur balita (bulan) } & Total \\
\cline { 2 - 4 } & $\begin{array}{c}12-23 \\
\mathrm{n}=16.950\end{array}$ & $\begin{array}{c}24-35 \\
\mathrm{n}=17.966\end{array}$ & $\begin{array}{c}36-47 \\
\mathrm{n}=18.990\end{array}$ & $\begin{array}{c}48-59 \\
\mathrm{n}=16.744\end{array}$ & $\mathrm{n}=70.650$ \\
\hline Laki-laki & 51,2 & 50,7 & 52,2 & 50,2 & 51,1 \\
Perempuan & 48,8 & 49,3 & 47,8 & 49,8 & 48,9 \\
\hline
\end{tabular}

Tabel 3 menjelaskan tentang cakupan penerimaan kapsul vitamin A pada 6 bulan terakhir, terlihat bahwa anak balita di perkotaan lebih banyak menerima kapsul vitamin A dosis tinggi $(75,4 \%)$ dibandingkan dengan anak balita di perdesaan $(70,0 \%)$.

Cakupan kapsul vitamin $\mathrm{A}$ dosis tinggi menurut tempat tinggal ini sedikit berbeda dengan Laporan Riskesdas 2007 yang mengemukakan bahwa cakupan balita yang menerima kapsul vitamin $\mathrm{A}$ dosis tinggi lebih tinggi di perkotaan yaitu sebesar 74,4 persen sedangkan di perdesaan 69,7 persen. Perbedaan ini disebabkan karena dalam analisis ini dilakukan hanya untuk anak umur 12-59 bulan, sedangkan dalam Laporan Riskesdas 2007 analisis ditujukan untuk anak berumur 6-59 bulan.

Tabel 3

Proporsi penerimaan kapsul vitamin $\mathrm{A} 6$ bulan terakhir dan tempat tinggal pada balita 12-59 bulan, Riskesdas 2007

\begin{tabular}{lccc}
\hline \multicolumn{1}{r}{ Menerima kapsul vitamin A } & $\begin{array}{c}\text { Perkotaan } \\
\mathrm{n}=25.801\end{array}$ & $\begin{array}{c}\text { Perdesaan } \\
\mathrm{n}=44.849\end{array}$ & $\begin{array}{c}\text { Total } \\
\mathrm{n}=70.650\end{array}$ \\
\hline Ya & 75,4 & 70,0 & 72,0 \\
Tidak & 24,6 & 30,0 & 28,0 \\
\hline
\end{tabular}


Tabel 4 menyajikan persentase balita menurut umur dan status gizi. Pada tabel tersebut menunjukkan bahwa; status gizi balita berdasarkan Berat Badan menurut Umur (BB/U) memperlihatkan karakteristik bahwa semakin bertambah umur, status gizi kurang cenderung meningkat, sedangkan status gizi lebih cenderung menurun. Kecenderungan itu senada dengan hasil Risksdas 2007, yang mengungkapkan hal yang sama bahwa ; semakin bertambah umur, status gizi kurang cenderung meningkat sedangkan gizi lebih cenderung menurun.

Status gizi balita berdasarkan Berat Badan menurut Tinggi Badan (BB/TB) secara deskriptif menunjukkan bahwa status gizi kurus relatif konstan seiring dengan bertambahnya umur, sedangkan status gizi kurus sekali cenderung menurun seiring dengan meningkatnya umur. Hasil analisis Riskesdas 2007 juga mengungkapkan bahwa masalah gizi sangat kurus menurun seiring dengan meningkatnya umur.
Sementara itu status gizi dengan indikator Tinggi Badan menurut Umur (TB/U) menunjukkan bahwa status gizi pendek cenderung meningkat sampai kelompok balita berumur $36-47$ bulan $(20,5 \%)$ dan cenderung menurun pada kelompok balita berumur 48-59 bulan $(19,9 \%)$. Status gizi sangat pendek cenderung menurun sejalan dengan bertambahnya umur, terendah pada balita kelompok umur 48-59 bulan (18, \%). Status gizi sangat pendek pada Riskesdas 2007 angkanya berfluktuatif, awalnya naik sampai pada kelompok umur 24-35 bulan kemudian cenderung menurun dan terendah didapatkan pada balita dengan kelompok umur 48-59 bulan $(14,8 \%)$.

Kecenderungan menurun pada status gizi sangat pendek sama dengan yang didapatkan antara analisis lanjut dengan hasil Riskesdas namun angkanya sedikit berbeda mungkin disebabkan karena batasan kelompok umur pada Riskesdas sampai pada batas 60 bulan.

Tabel 4

Persen sampel balita 12-59 bulan menurut umur dan status gizi, Riskesdas 2007

\begin{tabular}{|c|c|c|c|c|c|c|}
\hline \multirow{2}{*}{ Indeks } & \multirow{2}{*}{ Status gizi } & \multicolumn{4}{|c|}{ Umur (bulan) } & \multirow{2}{*}{ Tota } \\
\hline & & $12-23$ & $24-35$ & $36-47$ & $48-59$ & \\
\hline \multirow[t]{4}{*}{$\mathrm{BB} / \mathrm{U}$} & BB lebih & 4,4 & 4,4 & 4,2 & 3,7 & 4,2 \\
\hline & Baik & 77,0 & 73,4 & 73,5 & 73,7 & 74,3 \\
\hline & BB kurang & 12,4 & 15,2 & 15,5 & 16,4 & 14,9 \\
\hline & BB sangat kurang & 6,2 & 7,0 & 6,9 & 6,2 & 6,6 \\
\hline \multirow[t]{4}{*}{$\mathrm{BB} / \mathrm{TB}$} & Overweight & 13,0 & 11,5 & 12,0 & 11,8 & 12,1 \\
\hline & Normal & 71,2 & 72,6 & 74,0 & 75,0 & 72,3 \\
\hline & Kurus & 7,6 & 8,0 & 7,6 & 7,7 & 7,7 \\
\hline & Sangat kurus & 8,1 & 7,9 & 6,5 & 5,5 & 7,0 \\
\hline \multirow[t]{3}{*}{$\mathrm{TB} / \mathrm{U}$} & Normal & 57,3 & 56,8 & 58,0 & 61,5 & 58,4 \\
\hline & Pendek & 17,9 & 19,6 & 20,5 & 19,9 & 19,5 \\
\hline & Sangat pendek & 24,7 & 23,6 & 21,5 & 18,7 & 22,1 \\
\hline
\end{tabular}

Data penyakit dalam satu bulan terakhir diperoleh dari hasil wawancara dengan kuesioner isian tanpa konfirmasi pemeriksaan laboratorium. Orangtua sampel sebagai responden ditanya oleh pewawancara apakah sampel anak balita pernah didiagnosa penyakit tertentu oleh tenaga kesehatan. Bagi yang tidak pernah didiagnosis ditanyakan lagi apakah sedang menderita gejala klinis yang spesifik dari penyakit tersebut. Untuk penyakit akut dan sering dijumpai ditanyakan penyakit dalam kurun waktu satu bulan terakhir sebelum pelaksanaan survei. Pelaksanaan Riskesdas 2007 bervariasi pertengahan sampai akhir tahun 2007 di 28 provinsi dan Agustus September 2008 di 5 provinsi.

Proporsi penyakit dalam satu bulan terakhir dan berdasarkan tempat tinggal disajikan pada Tabel 5. Penyakit ISPA didiagnosa lebih tinggi di perkotaan $(17,7 \%)$ dibandingkan dengan di perdesaan $(15,7 \%)$, namun sebaliknya gejala penyakit ISPA lebih tinggi didapatkan di 
perdesaan $(32,5 \%)$ dibandingkan dengan di perkotaan $(29,6 \%)$.

Pneumonia didiagnosa sama antara perkotaan dan perdesaan, namun dari gejala yang dikemukakan oleh responsden proporsi pneumonia di perdesaan sedikit lebih tinggi $(2,2 \%)$ dibandingkan dengan di perkotaan $(1,6 \%)$.

Penyakit demam tifoid dan diare keduanya didiagnosa lebih tinggi di perdesaan dibandingkan dengan di perkotaan, demikian pula dengan gejala yang dikemukakan, proporsi di perdesaan lebih tinggi dibandingkan dengan di perkotaan.

Sedangkan penyakit campak didiagnosa sedikit lebih tinggi di perkotaan $(2,5 \%)$ dibandingkan dengan di perdesaan $(2,4 \%)$, namun gejala yang dikemukakan oleh responden menunjukkan bahwa proporsi campak lebih tinggi di perdesaan (1,2 persen) dibandingkan dengan di perkotaan $(0,8 \%)$.

Tabel 5

Proporsi penyakit dalam satu bulan terakhir dan tempat tinggal pada balita $12-59$ bulan,

Riskesdas 2007

\begin{tabular}{llccc}
\hline \multirow{2}{*}{ Penyakit } & Diagnosa/ Gejala & Perkotaan & Perdesaan & Total \\
\hline \multirow{2}{*}{ ISPA } & Diagnosa & 17,7 & 15,7 & 16,4 \\
& Gejala & 29,6 & 32,5 & 31,5 \\
\hline \multirow{2}{*}{ Pneumonia } & Diagnosa & 1,0 & 1,0 & 1,0 \\
& Gejala & 1,6 & 2,2 & 1,9 \\
\hline \multirow{2}{*}{ Demam tifoid } & Diagnosa & 0,7 & 0,8 & 0,8 \\
& Gejala & 0,6 & 1,0 & 0,8 \\
\hline \multirow{2}{*}{ Diare } & Diagnosa & 10,7 & 12,1 & 11,6 \\
& Gejala & 4,4 & 7,1 & 6,1 \\
\hline \multirow{2}{*}{ Campak } & Diagnosa & 2,5 & 2,4 & 2,4 \\
& Gejala & 0,8 & 1,2 & 1,0 \\
\hline
\end{tabular}

Poporsi penerimaan kapsul vitamin $\mathrm{A}$ yang dikaitkan dengan proporsi penyakit dalam satu bulan terakhir dijabarkan dalam Tabel 6 .

Analisis bivariat dilakukan dengan tabulasi silang terutama untuk mengetahui perbedaan antara morbiditas penyakit dalam satu bulan terakhir dengan menerima atau tidak kapsul vitamin A dengan menggunakan uji Khi-kuadrat. Hasil yang didapat menunjukkan bahwa tidak didapatkan pengaruh antara balita yang menerima kapsul vitamin A dengan balita yang tidak menerima vitamin $A$ terhadap penyakit pneumonia, demam tifoid dan campak baik secara diagnosa maupun dengan gejala (p.>0.005).

Namun untuk penyakit ISPA dan diare menunjukkan bahwa balita yang tidak menerima kapsul vitamin A justru morbiditasnya lebih tinggi dibandingkan dengan yang menerima kapsul vitamin A ( $p<0.005)$. Sayangnya keterbatasan data analisis tidak dapat mengungkapkan jarak antara diagnosa penyakit dengan pemberian kapsul vitamin A dan lamanya penyakit yang diderita (diare). 
Tabel 6

Proporsi Penerimaan Kapsul Vitamin A dan Proporsi Penyakit

\begin{tabular}{|c|c|c|c|c|c|c|}
\hline \multirow{2}{*}{ Penyakit } & \multirow{2}{*}{$\begin{array}{c}\text { Diagnosa } \\
\text { Gejala }\end{array}$} & & \multicolumn{2}{|c|}{ Menerima kapsul vit $\mathrm{A}$} & \multirow{2}{*}{$X^{2}$} & \multirow[b]{2}{*}{$p$} \\
\hline & & & $\mathrm{Ya}$ & Tidak & & \\
\hline \multirow{4}{*}{ ISPA } & \multirow{2}{*}{ Diagnosa } & $\mathrm{Ya}$ & 17,6 & 13,5 & \multirow{2}{*}{174,30} & \multirow{2}{*}{$0,000^{*}$} \\
\hline & & Tidak & 82,4 & 86,5 & & \\
\hline & \multirow{2}{*}{ Gejala } & $\mathrm{Ya}$ & 32,5 & 29,0 & \multirow{2}{*}{68,27} & \multirow{2}{*}{$0,000^{*}$} \\
\hline & & Tidak & 67,5 & 71,0 & & \\
\hline \multirow{4}{*}{ Pneumonia } & \multirow{2}{*}{ Diagnosa } & $\overline{\mathrm{Ya}}$ & 1,1 & 0,9 & \multirow{2}{*}{1,886} & \multirow{2}{*}{0,091} \\
\hline & & Tidak & 98,9 & 99,1 & & \\
\hline & \multirow{2}{*}{ Gejala } & $\mathrm{Ya}$ & 1,9 & 2,0 & \multirow{2}{*}{0,372} & \multirow{2}{*}{0,281} \\
\hline & & Tidak & 98,1 & 98,0 & & \\
\hline \multirow{4}{*}{ Demam tifoid } & \multirow{2}{*}{ Diagnosa } & $\mathrm{Ya}$ & 0,8 & 0,7 & \multirow{2}{*}{0,614} & \multirow{2}{*}{0,231} \\
\hline & & Tidak & 99,2 & 99,3 & & \\
\hline & \multirow{2}{*}{ Gejala } & $\mathrm{Ya}$ & 0,8 & 0,8 & \multirow{2}{*}{0,189} & \multirow{2}{*}{0,349} \\
\hline & & Tidak & 99,2 & 99,2 & & \\
\hline \multirow{4}{*}{ Diare } & \multirow{2}{*}{ Diagnosa } & $\mathrm{Ya}$ & 12,2 & 10,0 & \multirow{2}{*}{67,728} & \multirow{2}{*}{$0,000^{*}$} \\
\hline & & Tidak & 87,8 & 90,0 & & \\
\hline & \multirow{2}{*}{ Gejala } & $\mathrm{Ya}$ & 5,9 & 6,5 & \multirow{2}{*}{7,424} & \multirow{2}{*}{$0,003^{*}$} \\
\hline & & Tidak & 94,1 & 93,5 & & \\
\hline \multirow{4}{*}{ Campak } & \multirow{2}{*}{ Diagnosa } & $\mathrm{Ya}$ & 2,5 & 2,2 & & \\
\hline & & Tidak & 97,5 & 97,8 & b,19/ & 0,012 \\
\hline & Geiala & $\mathrm{Ya}$ & 1.0 & 1,1 & 3043 & $\cap \cap 44$ \\
\hline & Gejala & Tidak & 99,0 & 98,9 & 3,043 & 0,044 \\
\hline
\end{tabular}

${ }^{*}$ Significant $(p<0,05)$

\section{BAHASAN}

Cakupan kapsul vitamin A dosis tinggi menurut tempat tinggal ini sedikit berbeda dengan Laporan Riskesdas 2007 yang mengemukakan bahwa; cakupan balita yang menerima kapsul vitamin A dosis tinggi lebih tinggi di perkotaan yaitu sebesar 74,4 persen sedangkan di perdesaan 69,7 persen. Perbedaan ini disebabkan karena dalam analisis ini dilakukan hanya untuk anak umur 12-59 bulan, sedangkan dalam Laporan Riskesdas 2007 analisis ditujukan untuk anak berumur 6-59 bulan.

Sedangkan hasil Riskesdas 2007 menunjukkan bahwa cakupan kapsul vitamin A menurut jenis kelamin anak tidak nampak adanya perbedaan, yaitu untuk anak laki-laki sebanyak 71,3 persen dan perempuan sebanyak 71,7 persen. Cakupan pemberian kapsul vitamin A cukup bervariasi dengan cakupan tertinggi pada kelompok umur 12-23 bulan $(77,3 \%)$. Dampak positif dari pemberian kapsul vitamin A pada anak akan terlihat jika cakupan minimal mencapai 70 persen. ${ }^{8}$
Tabel 3 menjelaskan tentang proporsi penerimaan kapsul vitamin A pada 6 bulan terakhir, terlihat bahwa anak balita di perkotaan lebih banyak menerima kapsul vitamin A dosis tinggi $(75,4 \%)$ dibandingkan dengan anak balita di perdesaan $(70,0 \%)$.

Hasil analisis status gizi menurut $B B / U$ dan BB/TB gambarannya mirip dengan Riskesdas 2007. Indikator Berat Badan menurut Umur $(\mathrm{BB} / \mathrm{U})$ memberikan gambaran tentang status gizi yang sifatnya umum dan tidak spesifik. Tinggi rendahnya presentase gizi buruk atau kurang mengindikasikan ada tidaknya masalah gizi balita tetapi tidak memberikan indikasi apakah masalah gizi tersebut akut atau kronis. Indikator BB/TB menggambarkan masalah gizi yang sifatnya akut.

Hasil analisis lanjut untuk status gizi menurut TB/U memperlihatkan bahwa terjadi kecenderungan penurunan persentase dari status gizi sangat pendek seiring dengan bertambahnya umur, ada sedikit perbedaan karena status gizi sangat pendek pada Riskesdas 2007 angkanya berfluktuatif, awalnya naik sampai pada kelompok umur 24-35 bulan 
kemudian cenderung menurun dan terendah didapatkan pada balita dengan kelompok umur 48-60 bulan (14,8\%). Sementara pada analisis ini pada kelompok umur 48-59 bulan status gizi sangat pendek sebanyak 18,7 persen. Hasil ini menunjukkan bahwa masih ada masalah gizi yang bersifat kronis meskipun cenderung menurun sejalan dengan bertambahnya umur.

Hasil analisis dari penelitian cakupan vitamin A dengan status gizi pada anak balita yang dilakukan di Ethiopia mendapatkan bahwa tidak ada hubungan antara cakupan kapsul vitamin A dengan underweight, wasting, dan stunting. Demikian pula analisis yang dilakukan pada penelitian di Kamboja juga menerangkan bahwa tidak ada risiko antara cakupan kapsul vitamin A dengan status gizi underweight, wasting, dan stunting.., 10

Suplementasi kapsul vitamin A pada analisis ini tidak terbukti mempengaruhi morbiditas dari penyakit pneumonia, demam tifoid dan campak baik secara diagnosa maupun dengan gejala. Terlihat dalam Tabel 6 proporsi anak balita yang sakit pneumonia, demam tifoid dan campak hampir sama antara anak yang mendapat dan yang tidak mendapat kapsul vitamin A. Bahkan pada anak balita yang mendapatkan kapsul vitamin A proporsi yang sakit ISPA dan diare lebih tinggi secara nyata dibanding yang tidak mendapatkan kapsul vitamin A dalam enam bulan terakhir.

Ada beberapa kemungkinan terhadap temuan hubungan antara kapsul vitamin $\mathrm{A}$ dan morbiditas dalam analisis ini. Penerimaan kapsul vitamin $\mathrm{A}$ bervariasi tiap anak sehingga dampaknya terhadap morbiditas juga bervariasi. Pertama adalah data yang diolah merupakan data sekunder Riskesdas 2007 yang tidak didisain untuk tujuan analisis ini,sehingga terdapat keterbatasan untuk menilai dampak kapsul vitamin A terhadap morbiditas. Kedua adalah desain studi Riskesdas adalah potong lintang (cross-sectional) dan bukan studi intervensi. Ketiga adalah metoda pengumpulan data dalam Riskesdas 2007 didasarkan pada pengakuan orangtua melalui wawancara terhadap penyakit yang diderita sampel anaknya satu bulan terakhir sebelum survei, bukan dengan pemeriksaan klinis. Yang keempat adalah waktu pelaksanaan Riskesdas yang bervariasi bulan pelaksanaannya. Bila survei dilakukan segera sesudah mendapatkan kapsul vitamin $A$, maka status vitamin $A$ anak akan naik dan berdampak pada peningkatan kekebalan tubuh. Namun jika survei dilakukan pada saat anak sudah lama mendapatkan kapsul vitamin A, misalnya sudah 4-5 bulan yang lalu, maka status vitamin $A$ anak sudah menurun kembali sehingga kekebalan tubuh juga sudah menurun.

Dengan demikian dampak pemberian vitamin A bervariasi tergantung pada bulan pelaksanaan Riskesdas. Kelima adalah kemungkinan adanya faktor perancu. Analisis dalam Tabel 6 belum memasukkan faktor yang kemungkinan sebagai perancu misalnya status gizi anak. Seperti diketahui bahwa terdapat hubungan yang erat antara penyakit dan status gizi. Status gizi kurang menurunkan tingkat kekebalan tubuh terhadap infeksi, dan infeksi menurunkan status gizi termasuk status vitamin A. Dalam tulisan ini tidak ditelaah lebih lanjut perbedaan proporsi yang menerima kapsul vitamin A menurut status gizi. Keenam adalah jumlah sampel yang cukup besar, sehingga uji Khi-kuadrat cenderung untuk mendapatkan hasil signifikan walaupun dengan perbedaan yang kecil.

Beberapa studi lain juga mencari hubungan antara vitamin A dan morbiditas. Hasil satu studi untuk mengevaluasi dampak suplementasi vitamin A dengan dosis 200.000 IU pada bayi umur kurang dari 6 bulan, dan $400.000 \mathrm{IU}$ pada anak umur 1-4 tahun ketika menderita pneumonia, mengungkapkan bahwa tidak ditemukan dampak yang nyata dari pemberian vitamin A selama pneumonia akut tersebut baik subsequent morbidity atau severe morbidity pada anak dengan status vitamin A marginal. ${ }^{11}$

Studi lain menjelaskan bahwa suplementasi kapsul vitamin A sekali setahun dengan dosis 200.000IU retinol + 40 IU vitamin E tidak mengurangi risiko diare berat pada anak. Namun anak yang menerima suplementasi kapsul vitamin A dua kali setahun dapat mengurangi risiko diare dengan dehidrasi sebesar 56 persen, dan 64 persen mengurangi risiko diare dengan durasi 5 hari atau lebih, tetapi bukan diare persisten (lebih dari 14 hari). Suplementasi vitamin A juga berassosiasi dengan ARI (acute respiratory infection) berat, tetapi tidak dengan moderate ARI. ${ }^{12}$

Suplementasi vitamin A mempunyai dampak nyata menurunkan morbiditas penyakit pada anak seperti diare, demam, conjunctivitis 
dan campak. Pendapat seperti ini dikemukakan dan diperkuat oleh studi dari beberapa peneliti lain. Namun tidak dapat membuktikan dampak penurunan morbiditas pada penyakit batuk. ${ }^{13}$

Sebuah analisis dari penelitian mengenai suplementasi vitamin A di Ethiopia mengungkapkan bahwa ternyata tidak ada hubungan antara cakupan kapsul vitamin A pada balita dengan morbiditas anak yaitu demam, nafas cepat sebagai indikasi pneumonia, infeksi mata, maupun diare. ${ }^{14}$ Demikian pula hasil penelitian di Kamboja juga tidak mendapatkan perbedaan nyata antara cakupan vitamin $\mathrm{A}$ dengan penyakit demam dan diare. ${ }^{10}$ Hal serupa didapatkan pada penelitian yang dilakukan pada anak Indonesia berumur antara 1 - 5 tahun yang menerima kapsul vitamin A, hasill penelitian mengungkapkan bahwa tidak terdapat perbedaan nyata antara suplementasi vitamin $\mathrm{A}$ dengan penurunan morbiditas dari penyakit batuk, demam dan diare. ${ }^{15}$

Dosis yang tidak optimal merupakan salah satu alasan mengapa beberapa penelitian tentang suplementasi vitamin A tidak dapat menurunkan morbiditas dan mortalitas, disamping faktor lain. Disarankan agar penelitian yang dilakukan hendaknya mencakup faktor sosial ekonomi masyarakat, status vitamin A dan status gizi secara individu serta musim ketika penelitian dilaksanakan. ${ }^{16}$

Hal yang sedikit bertentangan terjadi, yaitu pemberian kapsul vitamin A pada anak berumur antara 6 sampai 83 bulan dengan tanda sub klinis kekurangan vitamin A justru meningkatkan prevalensi morbiditas penyakit diare dan infeksi saluran pernafasan setelah dua minggu suplementasi kapsul vitamin $A^{17}$

Studi yang dilakukan berupa suplementasi vitamin A pada anak penderita diare yang dirawat dirumah sakit yang tidak berhubungan dengan campak atau kolera, menyatakan bahwa tidak ada keuntungan yang didapat jika kapsul vitamin A diberikan pada penderita diare tersebut. ${ }^{18}$

Telah dilakukan analisis data pre and post intervensi suplementasi vitamin A pada 4.770 anak umur 6-72 bulan yang diseleksi di distrik Tigray, Ethiopia Utara. Sebanyak 281 anak (sub sampel) diambil darahnya untuk pemeriksaan serum retinol. Hasilnya mengungkapkan bahwa suplementasi vitamin A menurunkan morbiditas penyakit demam, diare, campak, conjunctivitits dan memperbaiki status gizi (wasting, underweight) serta meningkatkan serum retinol. ${ }^{19}$

Akses yang kurang terhadap intervensi vitamin A dan faktor demografi berkontribusi pada peningkatan malnutrisi, mortalitas dan morbiditas pada anak yang luput dari program suplementasi vitamin A. Hasil analisis dari data National Surveillance System di Indonesia mengungkapkan bahwa; anak balita yang tidak menerima suplementasi vitamin A kemungkinan juga tidak menerima imunisasi pada keluarga dengan bayi dan anak balita dan mempunyai mortalitas lebih tinggi dibandingkan dengan anak yang menerima vitamin $A$. Anak yang menerima vitamin A mempunyai morbiditas lebih rendah pada proporsi anemia, diare pada seminggu terakhir, diare akut dan demam. ${ }^{20}$

Dengan demikian, berbagai studi hubungan antara vitamin A dan morbiditas mempunyai hasil yang tidak konklusif. Beberapa studi menunjukkan hasil menurunkan morbiditas beberapa penyakit, sebagian studi dengan hasil tidak berbeda, dan beberapa studi justru meningkatkan morbiditas beberapa penyakit.

\section{SIMPULAN}

Suplementasi kapsul vitamin A pada analisis ini tidak mempengaruhi morbiditas dari penyakit pneumonia, demam tifoid dan campak baik secara diagnosa maupun dengan gejala. Morbiditas penyakit ISPA dan diare justru lebih tinggi pada anak yang menerima kapsul vitamin A enam bulan yang lalu, sama seperti hasil studi di Haiti. Berbagai kemungkinan dapat terjadi hasil studi ini karena desain studi potong lintang, data sekunder dengan tujuan berbeda, bulan pelaksanaan studi yang bervariasi, metoda pengumpulan data, jumlah sampel yang besar, dan faktor perancu.

\section{UCAPAN TERIMA KASIH}

Ditujukan kepada Tim penanggung jawab dari manajemen data Badan Litbang Kesehatan yang telah memberikan izin kepada kami untuk melakukan analisis lanjut mengenai kapsul vitamin $\mathrm{A}$ dan morbiditas anak balita.. 


\section{RUJUKAN}

1. Sommer A, Tarwotjo I, Djunaedi E, WestK, Loeden R, Mele L. Impact of vitamin A supplementation on childhood mortality. Lancet. 1986;1:1169-1173.

2. Ross DA. Recommendations for vitamin A supplementation. Journal of Nutrition. 2002; 132: 2902S-2906S.

3. Helen Keller International. National vitamin A supplementation campaign activities: August 2001. Indonesia Crisis Bulletin. 2001;3:1-4.

4. Semba RD, Susatio B, Muhilal, Natadisastra G. The decline of admissions for xerophthalmia at Cicendo Eye Hospital, Indonesia,1981-1992. Int Ophthalmol. 1995;19:39-42.

5. Grotto I, Mimouni M, Gdalevich M, Mimouni D. Vitamin A supplementation and childhood morbidity from diarrhea and respiratory infections: A meta-analysis. J Pediatrics. 2003; 142 (3): 297-304.

6. Feachem RC. Vitamin A deficiency and diarrhea: A review of interrelationships and their implications for the control of xerophthalmia and diarrhea. Tropical Diseases Bulletin.1987;84(3):R1-R16.

7. Kementerian Kesehatan RI. Riset Kesehatan Dasar (Riskesdas) 2007. Jakarta: Badan Litbangkes; 2008.

8. Horton S, Begin F, Greig A, Lakshman A. Micronutrient supplement for child survival. Working paper October 2008. Available from:

http://www.copenhagenconsencus.com

9. Semba RD, de Pee S, Sun K, Bloem MW, Raju VK. Coverage of the national vitamin A program in Ethiopia. J. Trop. Pediatrics. 2007; 54 (2): 141-144

10. Grover DS, de Pee S, Sun K, Raju VK, Bloem MW, and Semba RD. Vitamin A supplementation in Cambodia: Program coverage and association with greater maternal formal education. Asia Pacific Journal of Clinical Nutrition. 2008; 17 (3): 446-450.

11. Lucio CN, Paul A, Betty RK, Saul SM, Araci $\mathrm{CC}$ and Adriana FB. The impact of vitamin A supplementation given during a pneumonia episode in the subsequent morbidity of children. Tropical Medicine and International Health. 1998; 3 (8): 661-668.

12. Iman Sumarno, The impact of vitamin $A$ supplementation on the incidence of severe diarrhea and ARI in children in Nepal. Dissertation. Michigan: The University of Michigan; 1994.

13. Dowell, SF, Papic Z., Bresee JS et al . Treatment of respiratory syncitial virus infection with vitamin $A$ : $A$ randomized placebo controlled study trial in Santiago, Chile.Pediatr. Infet. Dis. J. 1996; 15:782786.

14. Gebremedin S, Loha E, Abebe Y, Dese G. Assessment of vitamin A supplementation coverage and its association with childhood illness in Boloso Sore Woreda, Welayta Zone, SNNP Region, Ethiophia. Ethiop.J.Health Dev. 2009; 23(3): 223-9.

15. Abdeljaber $\mathrm{MH}$. Abdeljaber, Monto AS, Tilden RL, Schork MA, Tarwotjo I. The Impact of Vitamin A supplementation on morbidity:A randomized community intervention trial. Am J Public Health. 1991; 81: 1654-1656.

16. Beaton $\mathrm{GH}$, Martorell $\mathrm{R}$, Abbe $\mathrm{KA}$ et al. Effectiveness of vitamin A supplementation in the control of young child morbidity and mortality in developing countries, Report to CIDA. Toronto: University of Toronto; 1992.

17. Stansfield SK, Pierre-Louis M, Augustin A, Lerebours A. Vitamin A supplementation and increased prevalence of childhood diarrhoea and acute respiratory infections. The Lancet. 1993; 342 (8871): 578-582

18. Henning B, Stewart K, Zaman K, Alam AN, Brown KH, Black RE. Lack of therapeutic efficacy of vitamin A for non-cholera, watery diarrhoea in Bangladeshi children. European J Clin Nutr. 1992; 46(6): 437-443.

19. Haidar J, Tsegaye D, Mariam DH, Tibeb HN, Muroki NM. Vitamin A supplementation on child morbidity. East African Med $\mathrm{J}$. 2003; 80 (1).

20. Berger SG, de Pee S, Bloem MW, Halati S, Semba RD. Malnutrition and morbidity are higher in children who are missed by periodic vitamin A capsule distribution for child survival in rural Indonesia. J. Nutr. 2007:137: 1328-1333. 